Dhaka Univ. J. Biol. Sci. 22(1): 21-28, 2013 (January)

\title{
REGENERATION OF INORGANIC NUTRIENT IN SEDIMENT WATER INTERFACE BY PSEUDOMONAS PERFECTOMARINA
}

\author{
Md. AbDUl Karim* AND Kimio FUKAMI \\ Laboratory of Aquatic Environmental Science, Faculty of Agriculture, Kochi University, \\ Otsu 200 Monobe, Nankoku, Kochi 783-8502, Japan
}

Key words: Pseudomonas perfectomarina, Sediment water interface, Regeneration

\begin{abstract}
Pseudomonas perfectomarina was isolated from a eutrophic bottom environment and introduced to stimulate heterotrophic and decomposing activities. The bacterial cells re-suspension was added to the experimental system after absorbing with porous substrates. The strain enhanced net regeneration of dissolved inorganic nitrogen and inorganic phosphorus from the sediment by two to fivefolds at different temperatures. The bacteria P. perfectomarina enhance net regeneration of 83.20, 148.08, 127.58 and $193.31 \mu \mathrm{M}$ dissolved inorganic nitrogen and 14.12, 13.24, 14.43 and $23.21 \mu \mathrm{M}$ dissolved inorganic phosphorous from the sediment at $20,23,24$ and $26^{\circ} \mathrm{C}$, respectively. Results suggested that the application of $P$. perfectomarina with substrates would be promising for improvement of eutrophic sediment water interface during summer.
\end{abstract}

\section{Introduction}

The growth in aquaculture has led to an increase in the use of feeds applied to water for improving production. However, only a small portion of the total nutrient input is recovered as the harvest of cultured organism(1). Traditionally, the nutrient wastes, mainly in the form of ammonia, nitrite, nitrate, phosphorus and organic matter have been delivered into the surrounding environments without giving little thought to their holding capacity ${ }^{(2)}$. The wastes lead the hypernutrification of the water column and sediment which in turn has been found to have serious ecological and economical impacts on the recipient ecosystems ${ }^{(3)}$. This organic enrichment has also caused lowered productivity in farms and increased mortality of the cultivated fish ${ }^{(4)}$.

Water-column nutrient recycling by bacteria and other heterotrophic organisms is a dominant process supplying nutrients to phytoplankton in photic zones of both marine and fresh water ecosystems. The contribution of bacteria in nutrient regeneration depends on the chemical composition and supply rates of available bacterial substrates, temperature, and food-web structure and dynamics ${ }^{(5)}$. Dissolved organic nitrogen (DON)

*Author for correspondence: Department of Botany, University of Dhaka, Dhaka-1000, Bangladesh. <akarim@du.ac.bd>. 
is actively released during photosynthesis and that low-molecular-weight compounds such as dissolved free amino acids are major substrates for bacteria(6). Phosphorus is found in fish feeds and is broken down into a more useable form (phosphate) through decomposition. In most cases phosphorus and nitrogen contribute to eutrophication in a watershed by promoting growth of algae. Watershed resource manager focused on reducing the amounts of phosphorus and nitrogen in a watershed when attempting to improve water quality. The major problem is to accelerate this metabolism sufficiently to cope with the rate at which the contaminant is delivered to the environment.

The study site Uranouchi Inlet, Kochi prefecture, Japan is highly eutrophic due to unlimited practices of fish cages with high protein nutrient input. In summer season microorganisms are active at high temperature but due to low DO in the study site it could not show their activity properly. So, stimulate the heterotrophic activities during summer, using bacterial strain that's active at high temperature with low DO concentration may be a possible way. Considering that, we tried to isolate promising bacteria that can be active during summer at high temperature although the DO concentration is limited ${ }^{(7)}$. Thus the objectives of the present study were: (i) Isolation of indigenous bacterial strains possessing high metabolic activities and (ii) stimulation of inorganic nutrient regeneration during summer at high temperature with low DO concentration.

\section{Materials and Methods}

Sampling station is a eutrophic area practicing intensive fish farming in cages. The sampling point was in vicinity of one of the farms and the average depth near the sampling point ranged $16-17 \mathrm{~m}$. Water samples were collected from bottom $(16 \mathrm{~m}$ depth) environment with Niskin water sampler (5 1 cap.), while sediment samples were collected by Ekman-Birge grab sediment sampler from surface sediment and kept into icebox. The study was carried out on May 10, June 21, July 5 and August 16, 2002.

For isolation of effective bacteria that might be active at bottom environment, authors collected bottom water and surface sediment sample from the study site. The fast growing bacterial strains isolated from the bottom water and sediment were 150 . Considering temperature dependent growth pattern and metabolic activity of the strain finally Pseudomonas perfectomarina was selected to use for the improvement of the sediment-bottom water interface( ${ }^{(8)}$.

All experiments were conducted in one liter glass bottle, which was previously washed in $2 \mathrm{~N} \mathrm{HCl}$ for two days. Sediment-water system was prepared by adding $50 \mathrm{~g}$ (wet weight) of sediment into the bottle with one liter of sample water, where sample water was slowly added on to the sediment to avoid the profuse mixture and kept it for two hours to minimize the disturbance effects ${ }^{(9)}$ and transparency of the overlying water of sediment-bottom water complex system could be assured by visual estimation(10). 
Bacterial broth culture was centrifuged at $10000 \mathrm{rpm}$ (Himac CR 21E, Hitachi) for 10 minutes at $10^{\circ} \mathrm{C}$. The supernatant was discarded and bacterial cells' plate was gently rinsed with filter-sterilized $(0.22 \mu \mathrm{m})$ sample water at least five times in order to remove associated nutrients and re-suspended with the same filtered water by pipetting. Three $\mathrm{ml}$ of bacterial cell re-suspension was used as inocula and introduced into the treatment bottles absorbing with substrates. In the control bottles same amount of substrates were used. The glass bottles were incubated in situ in dark at temperatures 20,23, 24 and $26^{\circ} \mathrm{C}$ during May, June, July and August, 2002, respectively for ten days. Dissolved oxygen concentration was monitored by YSI, Model No. 85/10 FT, at every sub-sampling occasion.

Bacterial activities were evaluated by the changes of inorganic nutrient regeneration within the sediment-water interface during incubation. The fluxes were calculated by considering the first slope of dissolved inorganic nutrients released during incubation.

Just after adding bacteria, $25 \mathrm{ml}$ sub-samples were taken at the beginning of the incubation. At three days interval $25 \mathrm{ml}$ sub-samples were pipetted aseptically from $2 \mathrm{~cm}$ above the sediment surface of each bottle without any disturbance of the system and preserved at $-25^{\circ} \mathrm{C}$ temperature. Concentrations of dissolved inorganic nutrients in the sub-samples were measured by using automatic analyzer (Bran+Luebbe TRAACS 800).

\section{Results and Discussion}

For stimulation of the nutrient regeneration in sediment water interface, selected bacterial strain of Pseudomonas perfectomarina was added. During the incubation of sediment-water system collected in May and incubated at in situ at $20^{\circ} \mathrm{C}$, concentration of DIN and DIP released into the overlying water increased after addition of bacteria more than without addition (Table 1). In the results, the net releases of DIN and DIP, within sediment-water interface in a control parts were 69.04 and $1.70 \mu \mathrm{M}$, respectively, while in the system of adding bacteria they were increased 152.24 and $15.82 \mu \mathrm{M}$, respectively (Table 1). Total amount of added bacteria was $28.39 \%$ of the natural bacterial abundance (Table 2). The DO concentration changed during incubation from $3.65 \mathrm{mg} /$ at the beginning to $2.64 \mathrm{mg} /$ at the end (Table 3). Result of the experiment with sample collected on June and incubated at in situ temperature $23^{\circ} \mathrm{C}$ has been presented in Table 1. The net releases of DIN and DIP supplemented with P. perfectomarina were 180.75 and $19.22 \mu \mathrm{M}$ and those of control were 32.67 and $5.98 \mu \mathrm{M}$, respectively (Table 1).

Total amount of added bacteria was $27.75 \%$ of the natural bacterial population (Table 2). The DO concentration also changed from $1.83-0.38 \mathrm{mg} /$ (Table 3). 
Table 1. Changes in concentration of inorganic nutrients by adding P. perfectomarina at different in situ temperature.

\begin{tabular}{|c|c|c|c|c|c|c|c|c|c|c|c|c|c|}
\hline \multirow{3}{*}{ Months } & \multirow{3}{*}{$\begin{array}{l}\text { Incubation } \\
\text { temp. }\left({ }^{\circ} \mathrm{C}\right)\end{array}$} & \multicolumn{12}{|c|}{ Concentration of DIN $(\mu \mathrm{m})$} \\
\hline & & \multicolumn{6}{|c|}{ Without P. perfectomarina } & \multicolumn{6}{|c|}{ With P. perfectomarina } \\
\hline & & 0 & 2 & 4 & 6 & 8 & 10 & 0 & 2 & 4 & 6 & 8 & 10 \\
\hline May & 20.0 & 43.03 & 51.58 & 73.53 & 86.72 & 97.49 & 112.07 & 43.01 & 98.92 & 143.53 & 164.60 & 181.02 & 195.25 \\
\hline June & 23.0 & 69.65 & 79.33 & 83.18 & 87.27 & 99.42 & 102.32 & 80.4 & 140.28 & 171.93 & 223.22 & 247.51 & 261.15 \\
\hline July & 24.0 & 55.25 & 67.09 & 69.71 & 78.65 & 84.85 & 89.61 & 63.24 & 123.68 & 156.35 & 184.29 & 213.59 & 225.19 \\
\hline \multirow[t]{4}{*}{ Augst } & 26.0 & 66.56 & 82.78 & 95.74 & 106.62 & 122.1 & 127.53 & 69.81 & 176.55 & 249.97 & 277.03 & 303.81 & 324.1 \\
\hline & & \multicolumn{12}{|c|}{ Concentration of DIP $(\mu \mathrm{m})$} \\
\hline & & \multicolumn{6}{|c|}{ Without P. perfectomarina } & \multicolumn{6}{|c|}{ With P. perfectomarina } \\
\hline & & 0 & 2 & 4 & 6 & 8 & 10 & 0 & 2 & 4 & 6 & 8 & 10 \\
\hline May & 20.0 & 1.59 & 2.83 & 3.03 & 3.3 & 3.3 & 3.19 & 1.69 & 6.41 & 12.52 & 16.51 & 16.21 & 16.27 \\
\hline June & 23.0 & 2.42 & 3.87 & 5.22 & 6.97 & 8.41 & 8.4 & 3.34 & 9.32 & 16.78 & 21.15 & 22.31 & 22.56 \\
\hline July & 24.0 & 8.09 & 9.5 & 11.62 & 16.31 & 19.97 & 19.52 & 8.42 & 14.72 & 19.96 & 28.73 & 34.29 & 33.75 \\
\hline August & 26.0 & 5.54 & 6.9 & 8.44 & 9.13 & 9.3 & 11.53 & 5.6 & 21.09 & 32.35 & 32.57 & 27.05 & 22.06 \\
\hline
\end{tabular}

24 
Simultaneously, experiments with samples of July and August with incubated in situ temperatures at 24 and $26^{\circ} \mathrm{C}$, respectively have been conducted (Table 1). In the experiment of July, DIN concentration increased from $55.25-89.61 \mu \mathrm{M}$ in control, while after addition of bacteria it changed from $63.24-225.19 \mu \mathrm{M}$ (Table 1). Same trend also continued with the experiment of sample of August, changed from $66.56-127.53 \mu \mathrm{M}$ in control, while after addition of bacteria it changed from $69.81-324.10 \mu \mathrm{M}$ (Table 1). Accordingly, DIP concentration also increased from 8.09 - $19.52 \mu \mathrm{M}$ without adding bacteria and after addition it changed from 8.42 - $34.29 \mu \mathrm{M}$ in sample of July (Table 1). In the experiment of August, DIP concentration also increased from $5.54-9.30 \mu \mathrm{M}$ without adding bacteria and after addition it changed from 5.60 - $32.57 \mu \mathrm{M}$ (Table 1). Total added bacteria were 26.61 and $30.28 \%$ of the natural bacteria with sample of July and August, respectively (Table 2). The amount of DO also changed like before from 1.18 to $0.25 \mathrm{mg} /$ in sample of July and from 1.94 to $0.91 \mathrm{mg} /$ in sample of August (Table 3).

Table 2. Number of added bacterial cells and their ratio to natural bacterial abundances on different incubation occasions. Added bacterial stain was P. perfectomarina.

\begin{tabular}{lcccc}
\hline Months & $\begin{array}{c}\text { Incubation } \\
\text { temp. }\left({ }^{\circ} \mathrm{C}\right)\end{array}$ & $\begin{array}{c}\text { Total bacterial } \\
\text { abundance in } \\
\text { sediment }\left(\times 10^{10} \text { cells }\right)\end{array}$ & $\begin{array}{c}\text { Total added bacterial } \\
\text { abundance } \\
\left(\times 10^{10} \text { cells }\right)\end{array}$ & $\begin{array}{c}\text { Added bacteria : } \\
\text { Natural abundance }(\%)\end{array}$ \\
\hline May & 20.0 & 46.5 & 13.2 & 28.39 \\
June & 23.0 & 47.2 & 13.1 & 27.75 \\
July & 24.0 & 48.1 & 12.8 & 26.61 \\
August & 26.0 & 49.2 & 14.9 & 30.28 \\
\hline
\end{tabular}

Table 3. Changes in the concentration of dissolved oxygen (DO) at the initial and at the end of incubation on different incubation occasions. Used bacterial strain was $P$. perfectomarina.

\begin{tabular}{|c|c|c|c|c|c|}
\hline \multirow{3}{*}{ Months } & \multirow{3}{*}{$\begin{array}{c}\text { Incubation } \\
\text { temperature } \\
\left({ }^{\circ} \mathrm{C}\right)\end{array}$} & \multicolumn{4}{|c|}{ DO concentration $(\mathrm{mg} \Lambda)$} \\
\hline & & \multicolumn{2}{|c|}{ Without P. perfectomarina } & \multicolumn{2}{|c|}{ With P. perfectomarina } \\
\hline & & Initial & End & Initial & End \\
\hline May & 20.0 & 3.90 & 3.14 & 3.65 & 2.64 \\
\hline June & 23.0 & 1.73 & 1.43 & 1.83 & 0.38 \\
\hline July & 24.0 & 1.16 & 0.99 & 1.18 & 0.25 \\
\hline August & 26.0 & 1.84 & & 1.94 & 0.91 \\
\hline
\end{tabular}

The enhancement in the releasing rates of DIN and DIP after adding P. perfectomarina during experiment with samples collected in May, June, July and August are summarized in Table 4. During experiment in May, the releasing rates of DIN and DIP were $0.92 \pm 0.03$ and $0.13 \pm 0.01 \mathrm{fM} / \mathrm{d} /$ cell, respectively while after adding bacteria it changed to $17.94 \pm 2.23 \mathrm{fM} / \mathrm{d} /$ cell in DIN and $1.32 \pm 0.02 \mathrm{fM} / \mathrm{d} /$ cell in DIP, respectively 
(Table 4). In experiment with sample of June, releasing rates of DIN and DIP were $1.02 \pm$ 0.01 and $0.15 \pm 0.02 \mathrm{fM} / \mathrm{d} / \mathrm{cell}$, respectively while after adding bacteria it changed to 19.16 \pm 2.11 and $1.73 \pm 0.01 \mathrm{fM} / \mathrm{d} /$ cell, respectively (Table 4 ). Such enhancement were also noticed with samples of July, after adding bacteria DIN changes from $1.23 \pm 0.05$ to 18.98 $\pm 3.16 \mathrm{fM} / \mathrm{d} /$ cell and DIP changes from $0.15 \pm 0.01$ to $1.91 \pm 0.01 \mathrm{fM} / \mathrm{d} /$ cell, respectively (Table 4). The same trend has also been observed in experiment with sample of August, releasing rates of DIN and DIP were $1.65 \pm 0.04$ and $0.17 \pm 0.02 \mathrm{fM} / \mathrm{d} /$ cell, respectively while after adding bacteria it changed to $30.38 \pm 2.17$ and $4.64 \pm 0.07 \mathrm{fM} / \mathrm{d} / \mathrm{cell}$, respectively (Table 4).

Table 4. Changes in releasing rate of DIN and DIP fluxes after addition of P. perfectomarina at different in situ temperature.

\begin{tabular}{|c|c|c|c|c|c|}
\hline \multirow[b]{2}{*}{ Months } & \multirow{2}{*}{$\begin{array}{l}\text { Incubation } \\
\text { temp. }\left({ }^{\circ} \mathrm{C}\right)\end{array}$} & \multicolumn{2}{|c|}{ Releasing rate of DIN (fM/d/cell) } & \multicolumn{2}{|c|}{ Releasing rate of DIP (fM/d/cell) } \\
\hline & & $\begin{array}{c}\text { Without } \\
\text { P. perfectomarina }\end{array}$ & $\begin{array}{c}\text { With } \\
\text { P. perfectomarina }\end{array}$ & $\begin{array}{c}\text { Without } \\
\text { P. perfectomarina }\end{array}$ & $\begin{array}{c}\text { With } \\
\text { P. perfectomarina }\end{array}$ \\
\hline May & 20.0 & $0.92 \pm 0.03$ & $17.94 \pm 2.23$ & $0.13 \pm 0.01$ & $1.32 \pm 0.02$ \\
\hline June & 23.0 & $1.02 \pm 0.01$ & $19.16 \pm 2.11$ & $0.15 \pm 0.02$ & $1.73 \pm 0.01$ \\
\hline July & 24.0 & $1.23 \pm 0.05$ & $18.98 \pm 3.16$ & $0.15 \pm 0.01$ & $1.91 \pm 0.01$ \\
\hline August & 26.0 & $1.65 \pm 0.04$ & $30.38 \pm 2.17$ & $0.17 \pm 0.02$ & $4.64 \pm 0.07$ \\
\hline
\end{tabular}

Increased ammonium regeneration rates corresponding to increased numbers of bacteria were assumed to be caused directly by bacteria, whereas the absence of increased ammonium regeneration rates with increased particle density was assumed to indicate that most of the ammonium regeneration was done by organisms ${ }^{(11)}$. The increased rates of ammonium regeneration with increased added bacterial concentrations that we observed at several stations may indicate that bacteria themselves directly regenerate ammonium ${ }^{(12)}$ or may reflect the increased food supply made available to the bacterial grazers that would in turn cause regeneration rates to increase.

Soluble organic compounds attached to the plant and sediment surfaces are mainly degraded by bacteria aerobically. The oxygen needed to support the aerobic process is supplied directly from the atmosphere via diffusion through the sediment or wateratmosphere interface and by oxygen leakage from macrophytic roots ${ }^{(13)}$.

The strain $P$. perfectomarina enhanced net amounts and rates of inorganic nutrients (DIN and DIP) regeneration in overlying water column on the sample of May, when incubated in situ at $20^{\circ} \mathrm{C}$ (Tables 1 and 4). During this experiment, added bacterial densities were $28.39 \%$ of the natural bacterial abundance (Table 2). The results of the experiment conducted with samples collected in June incubated in situ at $23^{\circ} \mathrm{C}$ with added bacterial density $27.75 \%$ were also consistent with the experiment conducted in May (Tables 1, 2 and 4). 
Two more experiments were conducted; one was done with the sample of July that was incubated in situ at $24^{\circ} \mathrm{C}$ (Table 4). In this case added bacterial abundance was $26.61 \%$ to natural abundance (Table 2). The next experiment was done with sample of August and incubated in situ at $26^{\circ} \mathrm{C}$ (Table 4) and during this experiment the added bacterial abundance was $30.28 \%$ (Table 2 ).

Results of the experiments conducted with strain $P$. perfectomarina and incubated at different in situ summer temperatures showed that this strain could be effective and promising for the stimulation of decomposing sediment organic matter at high temperature $\left(20-26^{\circ} \mathrm{C}\right)$ with low DO concentration $(1.18-0.25 \mathrm{mg} \Lambda)$.

\section{Acknowledgements}

The authors are grateful to Professor Dr. T. Nishijima and Dr. M. Adachi for their valuable suggestions and help related to the study. Students of the laboratory of Aquatic Environmental Science (LAQUES) and the staff of the Marine Biological Research Center Usa, Japan helped during sampling and/or chemical or biological analysis for which the authors are thankful.

\section{References}

1. Hargreaves JA 1998. Nitrogen biogeochemistry of aquaculture ponds. Aquaculture 166: 181212.

2. Iwama GK 1991. Interaction between aquaculture and the environment. Crit. Rev. Environ. Control 21: 177-216.

3. Gowen RJ, H Rosenthal, T Makinen and I Ezzi 1990. Environmental impact of aquaculture activities. In: N. De Pauw and N. Wilkins (eds.). Aquaculture Europe '89-Business Joins Science European Aquaculture Society, Spec. Pub. No. 12, Bredene. pp. 1071-1080.

4. Håkanson L, A Ervik, T Mäkinen and B Möller 1988. Basic concepts concerning assessments of environmental effects of marine fish farm. Nordic Council of Ministers, Copenhagen. p. 103.

5. Haga $\mathrm{H}, \mathrm{T}$ Nagata and M Sakamoto 1995. Size-fractionated $\mathrm{NH}_{4}{ }^{+}$regeneration in the pelagic environments of two mesotrophic lakes. Limnol. Oceanogr. 40: 1091-1099.

6. Bronk DA, PM Glibert and BB Ward 1994. Nitrogen uptake, dissolved organic nitrogen release and new production. Science 265: 1843-1846.

7. Patel $\mathrm{AB}, \mathrm{K}$ Fukami, and $\mathrm{T}$ Nishijima 2000. Regulation of seasonal variability of aminopeptidase activities in surface and bottom waters of Uranouchi Inlet, Japan. Aquat. Microb. Ecol. 21: 139-149.

8. Karim MA and K Fukami 2011. Physiological characters of psychrotolerant bacteria in a eutrophic bottom environment. Dhaka Univ. J. Biol. Sci. 20(1): 49-56.

9. Hargrave BT 1975. Stability in structure and function of the mud-water interface. Verh. Int. Ver. Limnol. 19: 1073-1079. 
10. Novitsky JA 1983. Heterotrophic activity throughout a vertical profile of seawater and sediment in halifax harbor, Canada. Appl. and Env. Microb. 45: 1753-1760.

11. Gardner WS and JF Cavaletto 1997. Effects of natural light on nitrogen cycling rates in the Mississippi River plume. Limnol. Oceanogr. 43: 273-281.

12. Cotner JB and WS Gardner 1993. Heterotrophic bacterial mediation of ammonium and dissolved free amino acid fluxes in the Mississippi River plume. Mar. Ecol. Prog. Ser. 93: 75-87.

13. Negroni G 2000. Management optimization and sustainable technologies for the treatment and disposal/reuse of fish farm effluent with emphasis on constructed wetlands. World Aquacul. 31(3): 16-19.

(Manuscript received on 22 March, 2012; revised on 7 January, 2013) 